\title{
End-to-end real estate financialization: from developing to occupying through proptechs
}

Financeirização imobiliária em dois momentos: da produção à ocupação via proptechs

Rafael Kalinoski [I] Mario Procopiuck [II]

\begin{abstract}
During the last decade, new global real estate business models have expanded and gradually replaced the traditional landlord-tenant relationship intermediated by local companies. This paper analyzes how real estate production is transformed by financial capital within the context of real estate products directed to investors and rented via digital platforms. Methodologically, the qualitative investigation follows the money that finances real estate startups, known as proptechs, to identify the financial agents involved. The results suggest that real estate financialization continues to occur in construction and development but has now advanced towards occupation intermediated by companies permeated by financial capital. The conclusion is that real estate businesses have become more complex in four waves: financialization, financial-debureaucratization, financial-virtualization, and shared financialvirtualization of real estate occupation.
\end{abstract}

Keywords: real estate development; financialization; virtualization; real estate investment; proptechs.

\section{Resumo}

Na última década, proliferaram modelos de negócios imobiliários globais substitutivos da tradicional relação proprietário-locador intermediada por empresas locais. $O$ objetivo deste artigo é analisar como a produção imobiliária é transformada pelo capital financeiro sob a perspectiva dos produtos imobiliários direcionados a investidores com locação comercializada em plataformas digitais. Metodologicamente, a investigação qualitativa segue a "trilha do dinheiro" que financia as startups do setor imobiliário, conhecidas como proptechs, de modo a identificar os agentes financeiros envolvidos. Os resultados apontam que a financeirização imobiliária, além de continuar a ocorrer na construção e na incorporação, avança para a ocupação via empresas permeadas pelo mercado de capitais. Conclui-se que os negócios imobiliários se complexificam em quatro ondas: financeirização, financeiro-desburocratização, financeiro-virtualização e, por fim, financeiro-virtualização compartilhada da ocupação imobiliária.

Palavras-chave: produção imobiliária; financeirização; virtualização; investimento imobiliário; proptechs. 


\section{Introduction}

During the last 30 years, capitalism's tendencies have presented three significant phenomena: neoliberalism, globalization, and financialization (Epstein, 2005). While the first two have literary production that presents itself in a way one could call conclusive (Arantes; Vainer and Maricato, 2002; Harvey, 2005 and 2008; Mattos, 2007), the third one raises continued debate. While Western economies have de-industrialized in the last four decades by transferring production to the East (Harvey, 2008), they have observed a drop in tax revenue and a decrease in fiscal power, especially at the municipal level (Soares, 2020).

Then, the real estate product assumes a crucial role because it cannot be manufactured in Asia and exported to major capitalist countries, at least not in its final form. Cities then resort to this market sector to create jobs and boost the local economy. Along this process, the real estate product, which is the face of the local sphere and the fundamental unity of the urban form, starts to be permeated by capitalist political economy interests from the global sphere. That is because these global agents need to reinvest accumulated capital in other sectors of the economy (Guironnet; Attuyer and Halbert, 2015; Aalbers and Haila, 2018; August, 2020; Charles, 2020; and López, 2020).

The limits found by capital realization at the turn of the 21st century, which already counts two significant financial crises on a global scale (2008 and 2020), demand the reinvention of markets seeking to maintain profit-taking trajectories upward. To avoid the deacceleration of capital reproduction, the creative management of the real estate sector produces new ideologies to dwell in the urban space. These new ideologies appear in real estate propaganda through expressions such as "subscription living", "living without bureaucracy", "shared living", among others. These attempts at ideological conformation tend to circumscribe to the context of liberal inflection of the urban world order. The propagation of these ideologies is naturally accompanied by the offer of new products, which results in the constant reinvention of the standards of productive restructuring within the real estate sector.

The 2008 post-crisis period originated a business model in which large institutional investors acting on a global scale gradually replaced the traditional small landlord-residential investor focused on generating incoming via rent. The financial sector, which used to monetize mortgage debt and debt securitization, started to monetize long-term residential rental income. After all, it was precisely the high-risk tactics of monetizing mortgage and securitization bonds that lead to the market crash of 2008-2009 (Guironnet; Attuyer and Halbert, 2015; Charles, 2020; López, 2020).

In this context, new forms of real estate production emerged focused on invertors (either institutional or individuals) that rent their estate to obtain attractive rentability when compared to how much that same amount of money would yield if invested in fixed income bonds within a context of lowinterest rates, such as the case of Brazil now. In parallel, digital platforms emerged to facilitate the intermediation between the intentions of the real estate owner-investor and its target consumer. Additionally, compact apartments and studios appear more frequently within the new logic of the urban space rentier exploration because their sales value is more 
solvable than larger apartments. Because of that, compact estate fits a broader range of investment portfolios (Valfré and Ribeiro, 2020). New generations of consumers who gradually put aside the ideology of homeownership and begin to see housing as a service are the target audience of these new real estate products. This new ideology replaces the traditional social convention of considering the home the biggest and most important asset of a citizen or family. The less bureaucratic contracts that regulate these new commercial relationships slowly make the traditional renting model via local real estate agencies obsolete.

In the new circuit of real estate production, either through the construction of new buildings or the retrofit of old buildings in central areas, financial capital acts at both ends to obtain profitability via rent: in the construction of the building, through stock market capitalization of the largest developer companies; and in the occupation of the building, through stock market capitalization of digital platforms which intermediate the rental contracts, and through the rhetoric of financial asset attributed to real estate commercialized via real estate investment trusts (REITs) or crowdfunding. In this article, we call this sequence of relations between the financial market and the built environment end-to-end financialization: (I) development of the unities (construction and sales), and (II) occupation intermediated by technology companies that are also permeated by global financial capital.
Given practical and theoretical concerns about the impacts of these new strategies in the real estate-financial complex (Santoro and Rolnik, 2017; López, 2020; and Melo, 2021), this article explores how the second end of financialization happens. This second end happens when the financialized building is already part of the urban landscape. Then it enters the digital landscape of contemporary capitalism via platforms that potentialize the rentability for the owner-investor. In summary, the research problem presented is real estate production focused on investors as a phenomenon of urban space financialization. This problem emerges from the gap postulated by Fernandez and Aalbers (2016) on issues requiring research and theorizing, despite the existence of comprehensive analyzes on the financialization of everyday life. One of these questions is the financialization of housing and the importance of housing to financialization itself. Given that housing is a spatial phenomenon, this same gap is pointed out by Cavalcante et al. When they argue that "a specific attribute frequently omitted from the discussions on financialization is space" (2018, p. 194).

The importance of housing for the reinvention of the real estate market's operating logic will be explored, after a brief literature review, through the analysis of business models of real estate market startups, called proptechs, and the money trail that enables the expansion of these companies throughout the Brazilian territory. 


\section{Financialization and impacts at the material base of real estate market}

An important starting point to advance the debate and understand the articulation between capitalism and the urban spatial structure is called the "urban regime" (Abramo, 1995). According to the author, "the 'urban regimes' would identify particular phases of the relation between capital and the urban structure" (p. 511). At a given moment, the regime in force impacts urban space, which, in its turn, modifies itself as capitalist relations also change. The urban regime could then be the background of this discussion about the real estate production conducted to valorize invested capital and generate income.

In discussing financialization, there seem to be more questions than answers about its theoretical-conceptual framework. Nevertheless, these discussions are promising to explain a range of critical events from the last two decades. Since the 2008 mortgage bubble, for example, the occupation of the material home itself is relegated to the second plan. Meantime, the focus of the real estate market on the financial value of the property increased. In 2020, the "distancing economy" reinvented retail during the social distancing period demanded by the pandemic, and new rhetoric emerged to generate value through the transformation of the living space into the workspace as well. The reversal of financial losses from the beginning of the pandemic appears to be underway with the overvaluation of stock shares of companies capable of maintaining their commercial activities during confinement through wellstructured logistical networks. In this context, to contribute to filling the gap pointed out by Fernandez and Aalbers (2016), this article intends to explore the financialization of the residential real estate market and the new forms it has acquired in recent years.

Such as neoliberalism, financialization is not a monolithic phenomenon. It does not have a unique face because it varies among social contexts (Theodore; Peck and Brenner, 2009). One specific definition of financialization describes a pattern of accumulation in which profit-taking occurs through financial channels to the detriment of the production of commodities and product sales (Krippner, 2005). However, the real estate market needs to be produced by someone (the contractors) and sold by someone (the developers). Moreover, these two agency points demand financial investments in which profit-taking is continuously reinvented through new financial mechanisms such as traditional loans; initial public offerings (IPOs) and follow-on public offerings (FPOs) in stock exchanges; and the issuance of debentures, real estate receivables certificates (CRIs, in Portuguese), real estate letters of credit (LCls, in Portuguese), and REIT quotas (FIls, in Portuguese). In the wake of the reinvention of financial mechanisms, real estate business models are also reinventing themselves under the prism of digital evolutions, making it possible to de-bureaucratize rent and make this aspect of urban life something that can be solved on a smartphone. We will further explore this process in the Results section.

The financialization of development of the real estate product, called in this article the first moment of financialization, was 
thoroughly analyzed in the Brazilian academic literature, with highlights to Fix (2011), Rufino (2012), Sanfelici (2013), and the production of the Metropolises Observatory. The Observatory constantly looks at this process and its particularities throughout their continued studies on urban regimes. The first moment of residential real estate financialization in Brazil occurred when developers and builders made their IPOs in the stock exchange in 2006 and 2007 focused on the housing segment (Miele, 2008). Following that, these companies experienced sharp growth in production after the 2008 crisis, mainly due to funds from the Minha Casa, Minha Vida Federal Program and the dissemination of all sorts of financial titles backed in the real estate market (Fix, 2009; Fix and Paulani, 2019; Sanfelici, 2013; Sanfelici and Halbert, 2016 and 2019).

Publications and discussions from the last decade seem to converge towards the idea that there is an ongoing process of transforming the modus operandi of public institutions to make the normative acts of urban planning more flexible. This flexibility favors real estate businesses and allows large economic groups and their investors to capture urban development income (Martins, 2020; Panizzi, 2020). The interest of the municipal government - the ultimate representation of the State in urban management issues (Silva and Procopiuck, 2019) - in allowing such flexibility is centered on the argument that this would be one of the few alternatives to create jobs in times of deindustrialization and economic crisis (Soares, 2020). Academics also argue that the logic of financial relations operates the city and that "what matters is no longer how space is occupied, but the liquidity with which capital is realized" (Panizzi, 2020, p. 19). The built environment would, therefore, require a financial return competitive to the interestbearing capital.

The State and real estate market would appear, under such logic, increasingly intertwined in the production of urban space. The profit-taking aimed by the real estate market becomes crucial for the State to maintain its economic activity (Soares, 2020). Thus, the State assumes a central role in creating and maintaining conditions so that the real estate products remain as "financial commodities." That is because the State defines regulatory frameworks and can influence financial conditions of investments, including rentability (Halbert and Attuyer, 2016). The urban land, the base of the real estate production, is then priced as any financial asset; it is a price in the present reasoned on the expectation of a future value. The land market becomes, in essence, directly linked to financial issues (Fix and Paulani, 2019), and therefore dissipates a substantial part of its use values as the main structure of cities.

Considering this, a broader definition of financialization may suit this discussion better: it is "the increasing role of financial motives, financial markets, financial actors and financial institutions in the operation of the domestic and international economies" (Epstein, 2005, p. 3). Brazilian scholars also have a broad definition of the phenomenon that may enrich this discussion: financialization is the influence of finances over all aspects of society, overcoming the financial sector per se and conforming to the peculiarities of contemporary capitalism (Sanfelici, 2013). As will be evidenced by the following examples, financialized digital businesses are replacing 
local real estate dealers that intermediate rental contracts between landlords and tenants. The landlord is an investor in the new businesses models, and the tenant is a digital service subscriber. As this logic advances, proptechs replace the traditional real estate dealer. Furthermore, financial agents also permeate these digital platforms.

When we analyze the coverage of the financialization process, research highlights that it "mobilizes diverse scales, agents (financial and non-financial, public, and private), actions (material and discursive), and institutionalities in the transformation of economies, corporations and daily life itself" (Klink and Souza, 2017, p. 381). Along these lines, the liberalization of capital markets and the creation of new financial engineering constitute a favorable environment for the international circulation of financial flows on a considerably unprecedented scale. Several factors mark new businesses' projects and strategies, such as faster returns, early obsolescence of investments and assets, and intense spatial adjustments. Understanding this tangle of involved agents requires understanding the money trail, which we will address in the Methods section.

The need to find a place to absorb capital surplus also leads to the search for new markets and the promotion of new products and lifestyles, allied to mechanisms that make consumption of these novelties viable (Harvey, 2012). Then, urbanization actively contributes to capitalist development, which defines a restructuring of the real estate sector. Thus, it is necessary to concentrate on the premise that the real estate market does not only solve existing needs. It also creates new needs for which it then offers solutions. It is as if the creation of identities and ideologies under market logic modified the intimacy of private life, as long as the development of financial institutions is circumscribed in an emerging tendency of dominating every aspect of social relations (Cavalcante et al., 2018).

New models of real estate production also impact land management and city flows. Management may face such challenges as approving new developments with more units of smaller sizes. They may reasonably expect a new "typical resident" that prioritizes flows walking on foot, by public transit, or by ridehailing apps. In addition, such real estate developments are more "marketable" when located close to the best jobs and educational institutions. That can generate pressure from the real estate market to reframe degraded central areas through new developments or retrofitting old, abandoned, or underutilized buildings (Lacerda and Bernardino, 2020). Actions taken by the real estate market to launch new products in central areas considered "degraded" seem to gain momentum within the process of "creative destruction" (Harvey, 2012), which catalyzes new fronts for the sector to expand together with the ideological appeal of emerging lifestyles incorporated into the discourse of the second moment of financialization.

This second moment of the financialization process, however, seems not to have been thoroughly analyzed yet. It refers to the financialization of the real estate occupation, which occurs later and separately from the financialization of the building itself. Typically, the second moment of financialization happens through the sharing economy, which is subordinate to the logic of communication and information 
technologies, and was idealized in the North American post-2008 context. Rent without bureaucracy, mediated on a smartphone or computer to the detriment of the traditional street-level real estate dealer, seems to have come to stay. It has been causing disruptions in the sector, especially among "Generation Y" consumers (born between $\cong 1985$ and $\cong 1999$, also called millennials) and "Generation Z" consumers (born at the turn of the century). All of the aforementioned requires the second moment of financialization to be studied as a component of contemporary urban issues, which is one of the challenges undertaken in this article.

\section{Instrumentalization and local discussions on real estate financialization}

Instrumentally, the mechanisms that enable the financialization regime in the Brazilian urban space began to be institutionalized in the 1990s and have varied since then. Two important milestones were the REITs' implementation in 1993 and the Real Estate Financial System's (SFI, in Portuguese) in 1997. The SFI, with the guarantee of fiduciary alienation, enabled the creation of new fundraising instruments for the real estate market, such as CRIs and LCls (Santoro and Rolnik, 2017). Together, these mechanisms represented the beginning of securities traded in the financial market and backed by real estate values.

Focused on understanding this first moment of the real estate financialization, scholars gathered at the I International
Seminar: Financialization and Urban Studies (USP, São Carlos, 2018) to share their findings. This seminar had in its closing panel a feeling of satisfaction for having aligned several studies on the matter to each other mixed with the agony of so many questions left open. Scholars returned to several parts of Brazil and other countries with more questions than answers after establishing how much still had to be elucidated and constantly investigated. This epistemological surveillance is essential within the context in which urban regimes reinvent themselves under the prism of the digitization of the economy and the growing accessibility that the typical citizen has to different types of investments.

With that in mind, Cavalcante et al. (2018) argue that financialization and urban space have a synergistic relationship. In this relationship, the socio-economic context and the built environment determine specific characteristics of the process that may differ from the broadly discussed AngloSaxon financialization model. According to the authors, Brazil has a dual economy characterized by a dynamic center and a dependent periphery. Such a duality was identified in their study by mapping financialization agents and concluding the concentration of more sophisticated financial agents in Southeastern, Southern, and part of the Midwestern regions. In contrast, the Northern and part of the Northeastern regions form a periphery of less sophisticated financial agents. Additionally, the center of sophisticated financialization is more connected to global markets and other peripheral areas.

These findings align with global discussions that show how national economies have unevenly distributed financial structures 
across them (Ioannou and Wójcik, 2021). In Canada, scholars identified a similar pattern. The penetrability of REITs across Canadian urban space is inversely proportional to regulated rent (August, 2020). The study shows that REITs own a more significant percentage of properties in provinces with no rent regulation or weak regulation. These findings corroborate the State's central role in enabling the exploration of space as a financial commodity. That is because the State coordinates the regulatory frameworks (Halbert and Attuyer, 2016).

The empirical study we will present from now on will contribute to understanding to which extent the advanced mechanisms of the second moment of financialization are also concentrated in Brazilian regions where the most sophisticated financial agents are. In addition, the expansion of mechanisms such as REITs that we will present is in line with the results published by August (2020) when we consider that there are no consistent policies of rent price control in Brazil. That lack of regulation allows financial mechanisms to reinvent themselves to extract the highest profits possible from urban land.

\section{Methods}

Our methodology is qualitative and centered on a documental analysis of companies acting in the segment of rental intermediation through digital platforms in Brazil (Chart 1). The macroeconomic context is taken as the background to interpret the new strategies of the real estate-financial complex in times of crisis. First, we identify the companies and some of their enterprises that illustrate their segment of operation. Then we follow the money involved in their enterprises to understand what agents are involved in the first and second moments of financialization (end-to-end financialization). Our focus, nevertheless, is always in the second moment, which concerns how proptechs are leasing the real estate product. Understanding these companies' structure and modus operandi is vital for understanding the capital flows that structure the financialization network. It is relevant to highlight that our investigation focuses on the business models, not the business themselves. The actual examples are only mentioned to illustrate the main characteristics of these business strategies applied by over one thousand similar companies in Brazil alone. ${ }^{1}$

It is necessary to highlight that, based on this initial study, a qualitative analysis of paradigmatic cases of real estate financialization can lead to generalizations of the phenomenon. In addition, analyzing all proptech platforms competing with those dealt with in this article would be unfeasible at this exploratory stage, as it would require researching the real estate market in all capitals and medium-sized cities throughout the country. However, a detailed analysis of some critical cases allows us to advance the understanding of a phenomenon that still has relatively little scientific investigation made about it. Furthermore, as the research explores companies whose operations stand between the technology sector and the real estate sector, business models have been rapidly evolving at the speed of advances in the virtualization of social relations. 
Chart 1 - Researched companies

\begin{tabular}{|c|c|c|c|c|}
\hline \multirow{2}{*}{ Proptechs } & \multirow{2}{*}{ Geographical area of operation } & \multirow{2}{*}{ Business segment } & \multicolumn{2}{|c|}{ Channels } \\
\hline & & & Website & App \\
\hline Airbnb & Global scale & Very short-term rental (min. 1 day) & Yes & Yes \\
\hline Housi & $\begin{array}{l}\text { City of São Paulo, with expansion } \\
\text { plans to other capitals, } \\
\text { medium-sized cities, and Latin } \\
\text { America }\end{array}$ & $\begin{array}{l}\text { Medium-term and long-term rentals } \\
\text { (min. } 1 \text { month) }\end{array}$ & Yes & Yes \\
\hline $\begin{array}{l}\text { Quinto } \\
\text { Andar }\end{array}$ & $\begin{array}{l}\text { Capitals of AM, ES, DF, GO, BA, } \\
\text { PA, and PE states; capitals and } \\
\text { medium-sized cities of MG, RS, PR, } \\
\text { SC, SP, and RJ states }\end{array}$ & $\begin{array}{l}\text { Medium-term and long-term rentals (no } \\
\text { minimum, though most units demand } \\
\text { that lessee to insert furniture, focusing } \\
\text { on longer terms) }\end{array}$ & Yes & Yes \\
\hline Shortstay & City of Curitiba & $\begin{array}{l}\text { Short-term and médium-term rentals } \\
\text { (min. } 1 \text { month) }\end{array}$ & Yes & No \\
\hline Yuca & City of São Paulo & $\begin{array}{l}\text { Shared living without a fixed term in } \\
\text { properties renovated and decorated by } \\
\text { Yuca itself }\end{array}$ & Yes & Yes \\
\hline Roomgo & Global scale & $\begin{array}{l}\text { Shared living without a fixed term, at the } \\
\text { company the unit owner or other users. }\end{array}$ & Yes & No \\
\hline
\end{tabular}

Source: authors, 2021. Data from July 2021.

At our initial research approach, we had no pre-understanding of the capital structure and operating strategies behind each analyzed company. However, there was the perception that they offered similar services: uncomplicated, digital, non-guarantor rental, intermediated from start to end by digital channels. There was also the perception that the properties marketed on these platforms had their marketing in launch catalogs, websites, and social networks aimed at a younger audience willing to adhere to a routine in compact apartments, though well located in urban space. At times, the developers seem to attempt adding value to properties by associating them with attributes of the cities, highlighting proximity to public transit, their location in neighborhoods where the bestpaying jobs, and where the best educational institutions are concentrated.

We extracted the data compiled in this article from each company's website, from journalistic sources that explore the dynamics of capital and investments in startups (such as Brazil Journal, Exame, InfoMoney, Terra, The New York Times, and Veja), and in the case of Airbnb, from a platform (AirDNA) that extracts and centralizes the number of active ads and the characteristics of the ads by city. Throughout four subsections of the Results section, we will present the systematized findings and interpret them in light of the previously discussed theoretical state-of-the-art. 


\section{Results}

We have divided our results and analysis of contemporary real estate dynamics into four waves: financialization, financialdebureaucratization, financial-virtualization, and shared financial-virtualization of the residential real estate occupation. These four identified categories seem to emerge systematically and structurally in the current empirical reality of the real estate market.

\section{The financialization \\ of the real estate occupation}

We can understand real estate production aimed at investors through two lenses. The first is what the literature has called the "real estate-financial complex": the superposition of the financial market to the real estate market with the final objective of valuing financial capital through the production and sale of the real estate product as material support for social and economic activities in the urban space (Santoro and Rolnik, 2017; López, 2020). This new structure forged processes of territorial restructuring, making the production of urban space primarily coordinated by the private sector.

The second lens to understand the phenomenon, now restricting our discussion to the Brazilian context, is the sequence of cuts to the basic interest rate (Selic rate) (Figure 1). The cuts allowed the real estate market to take more loans to invest in the sector because, at the end of the chain, the buyer also had better loan offers at lower interest rates. In parallel to the loss of attractiveness of investments

Figure 1 - Selic trajectory compared to the number of REITs investors in the São Paulo stock exchange (B3)

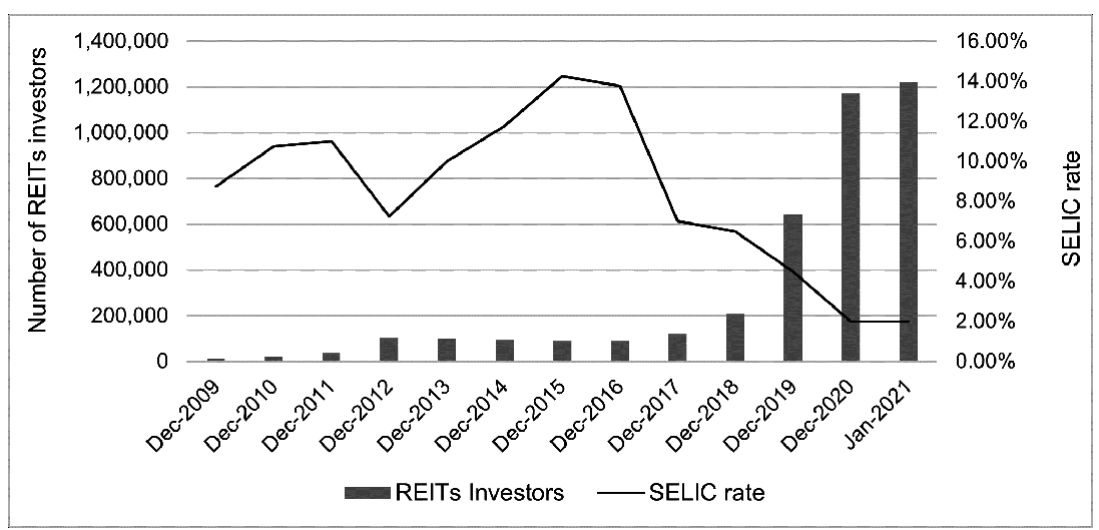

Source of data: Central Bank of Brazil and B3. Graph produced by the authors, 2021. 
whose benchmark is the Selic rate, two types of investments have become more common: investing in real estate to lease and investing in variable income (stocks and REITs, both traded in the stock market). It is necessary to mention that, although the Central Bank of Brazil has started to raise the Selic rate again after March 2021, the "real interest rate" (Selic rate minus inflation rate) is still negative as of July 2021.

Although buying estate to generate income permeates the entire history of urban Brazil, we are now discussing a new contour given by the possibilities brought to the real estate market by proptechs. If, before, the relationship between lessor and lessee was a relationship among known individuals, brokered or not by a local real estate dealer, now it is intermediated by digital platforms composed of global money through their presence in stock exchanges or venture capital. In such a way, the individual investor enters the real estate-financial complex as an owner-investor of real estate units or as a holder of real estate shares. This complex, which, in the first moment of financialization (development), was a three-sided relationship, becomes a quadrilateral relationship (Figure 2).

If at the first moment of financialization the highlight was the wave of development companies making initial offers at the stock exchange, we have two patterns to analyze at the second moment. The first pattern is traditional investors, which prefer tangible assets when the owners hold the key and the property deed. To them, the real estate market offers products that, when announced, are not advertising the living experience but rather the achievable profitability (Valfré and Ribeiro,

Figure 2 - Real estate-financial complex, or end-to-end financialization

FIRST MOMENT

Construction and Incorporation

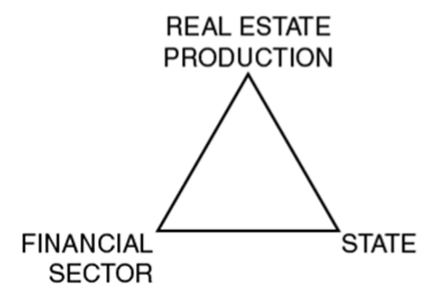

SECOND MOMENT

Occupation

Source: authors, 2021.

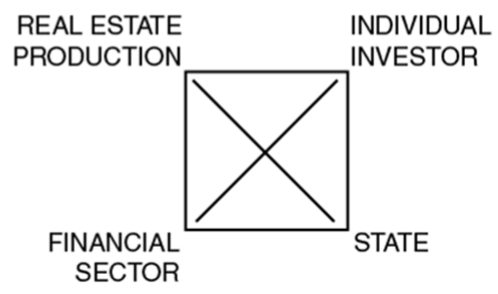


2020). This marketing appeal is evident among Brazilian developers in new enterprises by Vitacon (Figure 3) and Housi, their "subscription living" subsidiary. When located outside of São Paulo, Vitacon's hub, the units operated by Housi (or "Powered by Housi", as they like to call it), are developed by local companies that together form a network of real estate agents in the process of implementing subscription living (often compared to how Netflix works) throughout Brazil.

The second pattern to analyze is investors who are comfortable with holding nontangible assets, also called papers. In this case, financial resources for real estate are gathered by emitting stocks, quotas of REITs, or crowdfunding units that are circumscribed to a digital rent platform, as will be explored next. It is as if the nontangible investors would fund the tangible investment while the real estate market was only intermediating money flows through strategies that guarantee rentability to both. We can then argue that the real estate market has entirely entered the logic of financial markets.

As of now (July 3, 2021), the Brazilian stock exchange, called B3, has 360 REITs listed. Despite the longstanding tradition in funds of logistics warehouses, office floors, hospitals, schools, and bank branches, among others, residential real estate funds are a novelty that gained ground in 2020. It happened

Figure 3 - Sequence of Vitacon adds emphasizing the profitability of their products

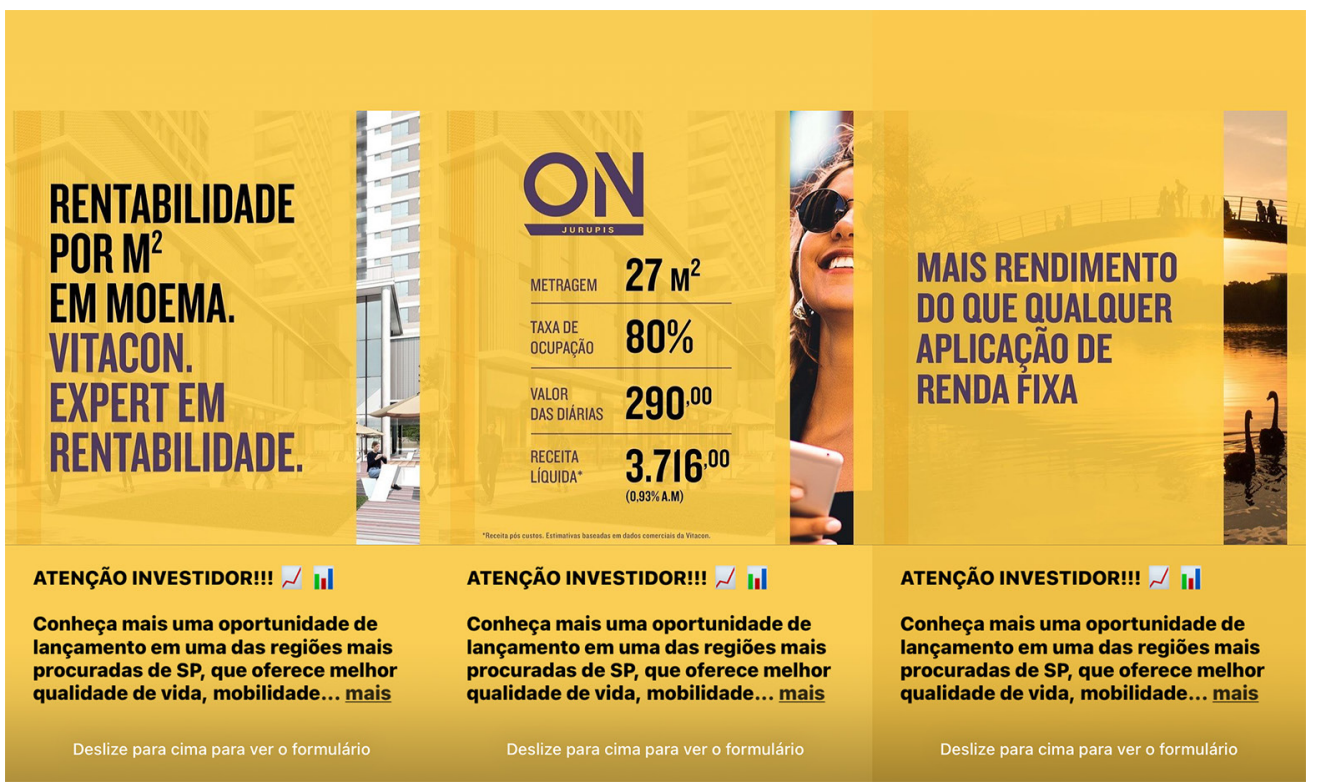

Source: sponsored Instagram adds posted by @vitaconoficial in January 2021. 
in the same context of a strong appeal for the profitability of residential real estate investment in detriment to investments in fixed income within the previously mentioned context of cuts to the interest rates. According to an InfoMoney article, a journalistic branch of the XP Group, 19 real estate investment trusts are somehow focused on the residential market (rent, development, sales), among which is a fund of Housi-operated buildings (D’Ávila, 2020). Although only mentioned in this article, the case of the expansion of REITs aimed at the residential market demands an exclusive research effort to be scrutinized and understood at an opportune moment.

Some companies called our attention because they reduce rent bureaucracy in Brazil by applying market strategies that allow them to sign fully digital contracts. Most of these contracts are also flexible about how long they last and admit rent payments via credit cards, a facility that may give lessees other benefits such as credit card points of cashback. In the upcoming three subsections of Results, we will present a panorama of the main strategies that compose the process of restructuring the rental market, delineating what we call the second moment of real estate financialization.

\section{The financial-debureaucratization \\ of the real estate occupation}

Operating in Brazil since 2012, the Silicon Valley company Airbnb is the most capillary among those discussed in this article. It was created in the post-2008 North American context when its founders decided to rent an air mattress in the bed and breakfast model (hence the name Air + bnb). A new international model of uncomplicated accommodation emerged, initially financed by venture capital, sometimes seen as unfair competition to the hotel industry.

In 2020, the company had the most expressive initial public offer at Nasdaq (Griffith, 2020). High demand for their shares brought the market value of Airbnb to USD 100 billion. Initially traded at USD 63, the shares closed their first day in the market at USD 144 (Sorkin et al., 2020), representing a high of $112 \%$ during its first day as a publicly traded company. It is important to note that the context of sharp valuation of the shares was the trillionaire injection of money in the North American economy made by the Federal Reserve. It raised speculation about a possible bubble in the financial market, given that the shares, especially those of the technology companies, were valued vertiginously amid the worse crisis of the decade. With new Federal stimuli at the beginning of 2021 and the market's positive reaction, the shares peaked at USD 216 on February 2, 2021.

Airbnb shares can be traded in Brazil since February 1, 2021, through Brazilian Depositary Receipts negotiated at B3. ${ }^{2}$ To understand the extent of Airbnb's operation in Brazil, we will restrict our discussion to the 15 core cities of "first-level urban networks", characterized as metropolises by the Brazilians Institute of Geography and Statistics in their 2018 study Region of Cities' Influences (IBGE, 2020). In Table 1, we present the profile of Airbnb's adds actives in Brazil and the medium rate charged for the units.

The data allows us to conclude that compact real estate (studios or one-bedroom) is the most announced on the platform and that the medium daily rate multiplied by 30 days suggests gross profitability above values 
Table 1 - Airbnb adds in Brazilian metropolitan core-cities

\begin{tabular}{|c|c|c|c|c|c|c|c|c|}
\hline \multirow{2}{*}{$\begin{array}{l}\text { Metropolitan } \\
\text { core city }\end{array}$} & \multirow{2}{*}{$\begin{array}{l}\text { Active } \\
\text { adds }\end{array}$} & \multirow{2}{*}{$\begin{array}{l}\text { Entire homes, } \\
\text { not shared (\%) }\end{array}$} & \multicolumn{4}{|c|}{ Types of pf units (\%) } & \multicolumn{2}{|c|}{$\begin{array}{l}\text { Medium rate } \\
\text { (In BRL) }\end{array}$} \\
\hline & & & Studios & 1-bd & 2-bd & 3-bd+ & $\begin{array}{l}\text { Daily rate } \\
\text { (a) }\end{array}$ & $\begin{array}{l}\text { Monthly } \\
\text { rate } \\
(=a * 30)\end{array}$ \\
\hline São Paulo & 12,159 & 67 & 17 & 59 & 18 & 6 & 196 & 5,880 \\
\hline Brasília & 1,095 & 76 & 18 & 71 & 6 & 5 & 145 & 4,350 \\
\hline Rio de Janeiro & 17,788 & 75 & 9 & 41 & 30 & 20 & 342 & 10,260 \\
\hline Belém & 451 & 60 & 7 & 45 & 29 & 19 & 139 & 4,170 \\
\hline Belo Horizonte & 1,581 & 54 & 5 & 39 & 29 & 27 & 159 & 4,770 \\
\hline Campinas & 834 & 57 & 10 & 50 & 17 & 23 & 154 & 4,620 \\
\hline Curitiba & 2,437 & 75 & 17 & 55 & 17 & 11 & 124 & 3,720 \\
\hline Florianópolis & 15,697 & 86 & 4 & 32 & 39 & 25 & 347 & 10,410 \\
\hline Fortaleza & 2,399 & 75 & 4 & 33 & 46 & 17 & 200 & 6,000 \\
\hline Goiânia & 1,102 & 78 & 11 & 57 & 22 & 10 & 141 & 4,230 \\
\hline Manaus & 530 & 60 & 6 & 51 & 29 & 14 & 123 & 3,690 \\
\hline Porto Alegre & 1,643 & 72 & 13 & 56 & 23 & 8 & 132 & 3,960 \\
\hline Recife & 1,692 & 72 & 8 & 50 & 27 & 15 & 165 & 4,950 \\
\hline Salvador & 3,785 & 72 & 7 & 45 & 25 & 23 & 214 & 6,420 \\
\hline Grande Vitória* & 3,570 & 85 & 2 & 21 & 39 & 38 & 250 & 7,500 \\
\hline
\end{tabular}

Data source: AIRDNA platform (airdna.co), collected on February 25, 2021. Table organized by the authors.

Note: data refer to adds circumscribed to the municipal limit of the core-city of each metropolis and not to the entire metropolitan area.

*In the case of Vitoria, the platform did not allow data from the municipality of Vitória to be separated from the metropolitan area called Grande Vitória.

of the conventional rental market. Besides that, in each of the metropolises, the ads tend to concentrate on specific regions of the city. In coastal cities, for instance, the concentration occurs along the beaches. In Curitiba, the concentration happens along the city's structural axis where the Bus Rapid Transit system runs.

The analysis of Airbnb's ads in Brazilian metropolises still has considerable research lacunes to be filled. However, our objective is to point out the importance of this global company over the dynamics of local real estate. We have noted that the financialdebureaucratization of the real estate occupation made possible by Airbnb has broad adherence throughout Brazilian territory, totaling more than 66,000 properties listed in the core municipalities of metropolises alone. This new, uncomplicated paradigm of short-term leasing seems to have induced the emergence of other proptechs that reproduce the non-bureaucratic model for medium and long-term leasing, adopting virtual space as the locus of financial transactions in real estate occupation. 
The financial-virtualization

of the real estate occupation

The developer Vitacon was founded in 2009 focused on the niche of compact real estate in Sao Paulo. In 2018, it founded a subsidiary company called Housi, which offers an unprecedented service in Brazil, called "subscription living". It is a type of rental contract similar to the hotel industry and Airbnb, though it is designed for more extended stays and facilitates alternating among different network units. Currently available in Sao Paulo, they plan its expansion to Brazilian medium-sized cities and, later, to Latin America.

Compact real estate is more solvable than traditional real estate because its sale value fits the investment portfolio of a larger group, making the transactions more liquid (Valfré e Ribeiro, 2020). When commercializing compacts, the real estate sector adopts a marketing discourse focused on profitability, often comparing it to fixed income at times of low-interest rates (the Selic rate is at $4,25 \%$ on July 3,2021). Besides that, this kind of marketing leans on the narrative of a new, uncomplicated lifestyle that does not depend on long-term loans or mortgages. Vitacon uses such a strategy incisively on social networks to advertise their products and market approach. Vitacon's CEO has stated to the SP Sonha podcast hosted by Veja that "Housing will increasingly be a service. You change houses according to changes at work, when you have kids, when they get married. You go from a larger unit to a smaller, dynamically. If life changes so often, it does not make sense to lock your money into a 30-year loan". ${ }^{3}$
Subscription living entered the financial market through at least two forms. In 2019, Redpoint, a venture capital management firm, invested 50 million reais in Housi. In 2020, Housi made na IPO of its REIT HOSI11, ${ }^{4}$ managed by Easynvest Gestão de Recursos Ltda. and administered by Vortx Distribuidora de Títulos e Valores Mobiliários Ltda. With a net worth of around BRL 54 million and 573,450 shares (data from January 29, 2021), the enterprise value per share was BRL 93. On that same date, the shares closed at BRL 85.32 on the stock exchange, with a P/EV of 0.92 , indicating the attractiveness of the investment, as the share trading price $(P)$ was below its enterprise value (EV). ${ }^{5}$

Despite Vitacon's vast business in São Paulo and Housi's expansion plans, only two enterprises are part of the HOSI11 REIT, Housi Jaú and Housi Urussuí, both under construction with an estimated lease date to 2023. The first one advertises a medium rent price of $B R L 3,100 / m o$ in 126 units ranging from 19 to $50 \mathrm{sqm}$, the other BRL 4,150/mo in 122 units ranging from 18 to $40 \mathrm{sqm}$. From the total REIT portfolio value, Housi Usussuí accounts for $61 \%$, Housi Jaú for $27 \%$, and $12 \%$ is the cash value.

The REIT is paying dividends to its shareholder even though the enterprises will not be leased until 2023. The dividend yield $^{6}$ varied from $0.57 \%$ of the quota value in November and December 2020 to $0.76 \%$ in October 2020. In this same period, with the Selic rate at $2 \%$, the attractiveness of this REIT for investors willing to take market risks in search of better profitability was high. Between July 31, 2020, and January 29, 2021, the REIT's shares were appreciated by $6.65 \%$, 
while the benchmarking of Brazilian REITs, the IFIX index, was appreciated by $5.34 \%$, according to the fund's report. It means that invested capital is appreciated due to the fluctuation in supply and demand of shares on the stock exchange and offered monthly earnings greater than three times the earning of typical savings accounts, for example, which pays only $70 \%$ of the Selic rate.

Beyond the HOSI11 REIT, Housi has the market approach of commercializing entire units of compact apartments to investors who prefer tangible assets. Even so, the unit can be entirely operated by the platform ("Powered by Housi", as they say), reducing the owner's burden of maintaining the property and the risk of default on the rental contract. Through the franchise model, Housi announced its expansion to 15 more cities in 2020 and predicted another 40 for 2021. By closing deals with franchisees, who are regional developers from different parts of Brazil, Housi offers its services in return for an unknown portion of the general sales value of the enterprises. "Housi is working as the software, the operating system for the buildings produced by partner developers", says the founder (Sambrana, 2021). Through the "plug in a property" function, Housi operates similarly to Airbnb, providing a platform to rent individual properties or entire buildings produced by other developers. Thus, Housi expands throughout Brazil independently from Vitacon, which only operates in São Paulo.

Concerning expanding their franchise model throughout Brazil, two projects under construction relate to the discussion on "reframing of central areas" through new projects or retrofitting old abandoned or underutilized buildings (Lacerda and
Bernardino, 2020). These are Viva Curitiba Studios, in downtown Curitiba and Infinita Town.co, in Porto Alegre. Both projects are lead by local developers and will be operated as Housi franchises. In both cases, local developers are retrofitting abandoned hotels in central areas to become 144 units ranging from 20 to 46 sqm in Curitiba and 180 units ranging from 20 to $30 \mathrm{sqm}$ in Porto Alegre. These will be fully decorated units, equipped for immediate living, and focused on investor buyers (Figure 4).

According to the rhetoric adopted when marketing these buildings, it is clear that the developers aim these projects at a target audience of residents inclined to an uncomplicated lifestyle, which opposes the traditional dream of homeownership and a private vehicle. It is a context of digitization of different spheres of urban life, according to which housing and transport services are just a touch away from a smartphone screen. The enterprises that operate on the Housi platform have several traditionally individual rooms of the apartment (laundry room and office, for example), converted into collective spaces (central laundry room and coworking), in addition to the possibility of hiring ondemand services, such as cleaning, through the company's app.

In Housi's case, the financialvirtualization of real estate occupation happens in two ways: (I) through the issuance of REIT quotas and (II) through the sale of units to investors who can "plugin" the apartment on their platform. These are, respectively, a form of (I) intangible investment through the sale of shares on the stock exchange; and a model of (II) tangible investment, through the sale of registered units that will be operated 
Figure 4 - Advertising material for Viva Curitiba and Town.co.

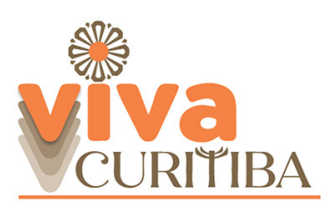

o jeito novo de investir
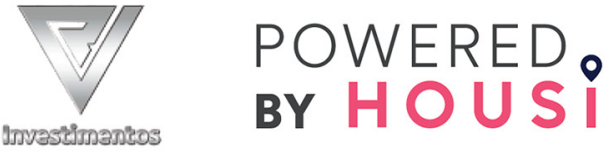

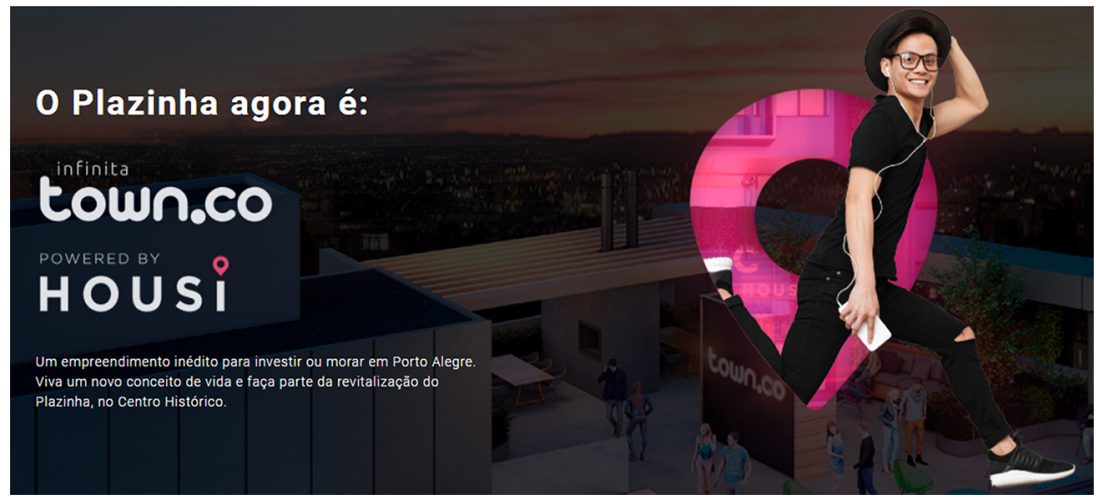

Source: Viva Curitiba Digitally distributed release catalog (2020) and Infinitetownco.com.br.

within the proptech system, taking from the owner the burden of finding a tenant, intermediating the contract, and assuming the risk of default. Operating in such forms, Housi absorbs both investors inclined to buy shares in the financial market and traditional investors, owners of entire properties. Either way, the virtual space made possible by communication and information technologies is central to the process.

Quinto Andar, another Brazilian proptech, offers a similar approach in the occupation of the real estate product by identifying itself as a "digital real estate broker" (Chart 2). Their business can make the traditional rental model via local, street-level real estate brokers obsolete by making rental without guarantor possible through digital credit analysis. In their platform, they centralize rental ads for properties spread across all parts of the country. If the person interested in renting is not approved in the credit analysis, they can hire insurance for a default scenario. For the property owner, Quinto Andar ultimately eliminates the risk of default. From the ad to the signing of the contract. All the negotiation is internetbased. 
Chart 2 - End-to-end financialization of enterprises advertised by Quinto Andar

\begin{tabular}{|c|c|c|l|}
\hline $\begin{array}{c}\text { Development } \\
\mathbf{1}^{\text {st }} \text { moment of financialization }\end{array}$ & Enterprise & \multicolumn{2}{|c|}{$\begin{array}{c}\text { Occupation } \\
\mathbf{2}^{\text {nd }} \text { moment of financialization }\end{array}$} \\
\hline \multirow{2}{*}{ Any developer } & Any enterprise & Quinto Andar & SoftBank (Japan) \\
\cline { 3 - 4 } & & & General Atlantic (US) \\
\cline { 3 - 4 } & & & Kaszek (Argentina) \\
\hline
\end{tabular}

Source of information: Veja (2019) and websites of investors. Table organized by the authors (2021).

Founded in 2013, Quinto Andar achieved the "unicorn"7 status after a 250 million dollar investment made in 2019 by the Japanese conglomerate SoftBank, focusing on technology, energy, and financial services. Other investors of the proptechs were the American General Atlantic, focused on growth equity, and the Argentinian Kaszek, which specializes in venture capital (Veja, 2019). This money trail allows us to notice how the traditional rental market, previously connecting landlords and tenants at a local scale, starts to be replaced by a nationwide business funded with capital from several other countries. It denotes that the financialvirtualization of the real estate occupation may address all sorts of contracts, from very short-term to long-term. Unlike Housi, Quinto Andar's business model advertises units of all sizes, from studios to multiple bedrooms, has a broader target audience, and focuses on a broader range of needs.

To conclude this group of proptechs, there is one restricted to the Curitiba market. Shortstay is a platform that intermediates the rental of furnished apartments and flats with flexible contracts of at least one month. Shortstay also accepts credit card rent payments, which represents another way of insertion for the financial sector through the profit of the financial transaction through a card operator. The company declares itself an "expert in the profitability of compact, central, and furnished apartments in Curitiba with a portfolio of more than 500 properties and thousands of lease contracts already signed". It also highlights its simplified negotiation compared to the rental model applied by traditional real estate brokers, notoriously time-consuming and bureaucratic.

The facilities offered by Shortstay, such as laundry services and bilingual services, denote the targeting of higher-income consumers that approach housing as a transitory need that allows mobility in a globalized world. One of the most recent enterprises marketed on the platform in 2018 is a condominium called All You Need. It is located in a region of downtown Curitiba where a gentrification process is in progress (Weigert, 2020). By following the money trail of this project, we realized that the circuit of capital begins and ends abroad. The leading partner of the enterprise developer is North American fund Equity International and, in addition to Shortstay, Airbnb and Booking also host ads for units at All You Need (Chart 3). 
When real estate developers launch an enterprise so that rental offers coincide on several platforms, they manifest such an intention in the advertising material before launching the property. We have observed this in the All You Need launch catalog and on the sponsored Instagram ads for the Vibe enterprise by Incorporadora Altma, under construction in Curitiba (Figure 5). Although the leading agent promoting Vibe is Housi, the developer clarifies that the rental system will be hybrid, seeking to reach competing platform users.

Chart 3 - Money trail of an enterprise financialized end-to-end.

\begin{tabular}{|c|c|c|c|}
\hline \multicolumn{2}{|c|}{$\begin{array}{c}\text { Development } \\
1^{\text {st }} \text { moment of financialization }\end{array}$} & Enterprise & $\begin{array}{c}\text { Occupation } \\
2^{\text {nd }} \text { moment of financialization }\end{array}$ \\
\hline \multirow{2}{*}{\multicolumn{2}{|c|}{$\begin{array}{l}\text { GT Building Developer, } \\
\text { Curitiba }\end{array}$}} & \multirow{3}{*}{$\begin{array}{c}\text { All You Need } \\
\text { 110, Riachuelo St. } \\
\text { Downtown, Curitiba }\end{array}$} & Airbnb (listed at Nasdaq) \\
\hline & & & $\begin{array}{l}\text { Shortstay (privately held local } \\
\text { company) }\end{array}$ \\
\hline $\begin{array}{l}\text { Equity International } \\
\text { Investment Fund, } \\
\text { Chicago }\end{array}$ & $\begin{array}{l}\text { THÁ Contractor, } \\
\text { Curitiba }\end{array}$ & & Booking (listed at Nasdaq) \\
\hline
\end{tabular}

Source: enterprise and developer websites. Table organized by the authors (2021).

Figure 5 - Fragments of advertisement of buildings developed for proptech rentals

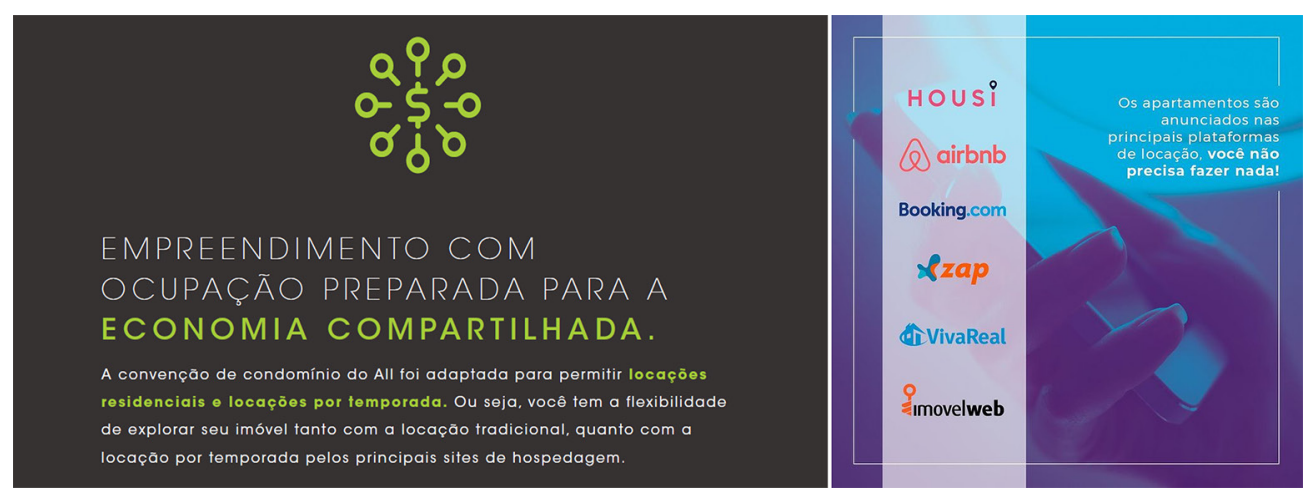

Source: All You Need release catalog snippet (left) and Instagram ad by the Altma developer for Vibe (right), both in Curitiba, PR, Brazil. 
The shared financial-virtualization

of the real estate occupation

Although Airbnb has consolidated its brand under the "sharing economy" paradigm, this study demonstrated (Table 2) that most properties advertised on the platform are entire homes, non-shared properties, closer to what the hotel industry offers than to cohabitation. Notwithstanding, we brought an example of another Brazilian proptech specifically focused on the intermediation of shared housing in renovated apartments in downtown Sao Paulo. Yuca identifies itself as "a Brazilian real estate technology startup with investors from all over the world, which offers an innovative solution for shared housing". The proptech operates a coliving model in which people who do not know each other share a home operated by Yuca. As well as the previously explored proptechs, Yuca also has a corporate structure on a global scale, as shown in Chart 4.
Through Yuca, the unit owner-investor can enter the real estate complex in two ways. First, as a direct owner of a property placed for rent on the platform, with all management intermediated by the company (tangible investment, called buy-to-rent). Second, in a way similar to the logic of REITs (intangible investment): through crowdfunding, it is possible to acquire shares of properties that have a more solvable minimum value for investors in general. Although founded with an exclusive focus on sharing, Yuca has begun to experiment with the niche of renting studios to individual residents and considers expanding it (Arbex and Samor, 2020).

The buy-to-rent model identifies potential properties in São Paulo through Yuca's "real estate curation" service. These properties are then announced on the platform along with the investment value, including acquisition, renovation of the property (which Yuca itself performs), furniture, taxes, and notary costs. The curatorship considers the

Chart 4 - End-to-end financialization of enterprises advertised by Yuca

\begin{tabular}{|c|c|c|c|}
\hline $\begin{array}{c}\text { Development } \\
1^{\text {st }} \text { moment of financialization }\end{array}$ & Enterprise & \multicolumn{2}{|c|}{$\begin{array}{c}\text { Occupation } \\
2^{\text {nd }} \text { moment of financialization }\end{array}$} \\
\hline Any developer & Any enterprise & Yuca & $\begin{array}{l}\text { Monashees (Brazil) } \\
\text { Terracotta Ventures (Brazil) } \\
\text { ONEVC (Brazil) } \\
\text { Creditas (Brazil) } \\
\text { Tishman Speyer (US) } \\
\text { Montage (US) } \\
\text { Individual investors }\end{array}$ \\
\hline
\end{tabular}

Source: Exame (Dias, 2021) and investors' websites. Table organized by the authors (2021). 
factors of yield, resilience, and the potential for appreciation of the real estate product after the renovation. In the only crowdfunding model currently announced (2020-2021), the minimum share of participation is $B R L$ 10,000 , and the expected return is $18.4 \%$ a year. Crowdfunding, in this case, refers to three properties and, legally, takes place through a Special Purpose Entity (SPE). Yuca focuses on high-income regions of São Paulo: Bela Vista, Brooklin, Consolação, Itaim Bibi, Jardins, Moema, Oscar Freire, Pinheiros, Vila Madalena, and Vila Olímpia, denoting that it is a model for consumers with high purchasing power. In November 2020, Yuca also created an investment fund of BRL 40 million, carried out with the assistance of Itaú BBA and funding from professional investors and institutions (Capelas, 2020).

Roomgo operates a similar business model. The English company connects owners with spare rooms and people looking for a space with those characteristics. The proptech is active in at least 20 countries across Europe, Oceania, Asia, and the Americas, including Brazil. Its digital channel intermediates shared living among property owners who want to monetize their underutilized space by having a tenant or users interested in an unoccupied property that can be rented to more than one person without cohabitating with their landlord, similar to what Yuca does.

In 2020, competitor SpareRoom, also British, acquired Roomgo, which belonged to the Digital Ventures group, becoming the world's largest service to find roommates. The SpareRoom and Roomgo brands remain private and without external investors (Property Notify, 2020). Keeping an ad at the top of the list of offers comes at a cost to the property owner and is one of proptech's revenue-generating mechanisms. The main innovation feature lies in the various mechanisms to find the best tenant-landlord pair. As Folha de S.Paulo newspaper puts it, the platform works as a Tinder of the real estate market. For example, it is possible to identify safe properties for the cohabitation of LGBTs, suggesting that mechanisms of internet-based rental evolve along with society's digitalization and transformation.

\section{Conclusions}

Our investigation outlines a new component of the urban regime in Brazil. Digital services have spread to facilitate rent contracts without bureaucracy and the extraction of income from the urban land. During the last decade, the urban property gradually distances itself from the local investor and approximates to global investors that can be institutional, individual, or investment funds. These ownersinvestors have the main objective of obtaining profits that are competitive to fixed income by commercializing living arrangements. Such a scenario represents an advanced transition stage from the traditionally local to the global real estate-financial complex permeated by rentier logic and the virtualization of real estate transactions.

We classified our analysis of business models in four waves of real estate occupation: (I) financialization, (II) financial-debureaucratization, (III) financialvirtualization, and (IV) shared financialvirtualization. These waves illustrate the intensification of the innovation process within the sector, which allows for innovation 
surplus income. New business models make users curious to experiment and, thus, the limits of the real estate market are pushed to a new level at each innovation. However, the innovation surplus in real estate may suggest increased living costs, which opens new research gaps to understand how the second moment of financialization mechanisms raise rental prices, which is already the most expressive component of the Brazilian housing deficit since 2011.

Under this logic, the most common real estate products are compact units because they are more solvable to the portfolio of investors focused on tangible assets and efficiently serve uncomplicated living arrangements through digital platforms. In this new model of businesses producing real estate to investors, the very personal relation of the building/ owner-landlord/real estate broker/lesseetenant kind transforms into a financial asset/ owner-investor/digital platform/subscriberlessee-guest kind of relation (Figure 6). Besides the financialization of the real estate development (first moment of financialization), the shareholder structure of companies intermediating rental contracts in virtual environments is also permeated by venture capital from a global scale or open in stock markets (second moment of financialization).

The conclusions of our investigation align with international discussions about neoliberal restructuring, governmental policies, and financial innovation that creates conditions

Figure 6 - Transition of the traditional real estate sector to the real estate-financial complex

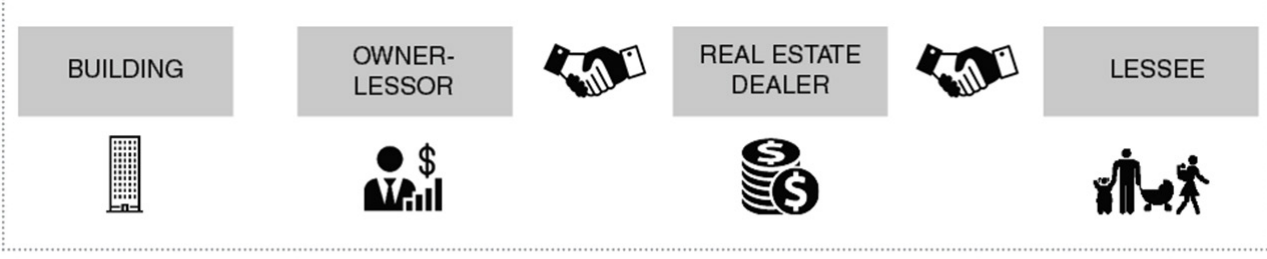

Personal-comercial relationship.

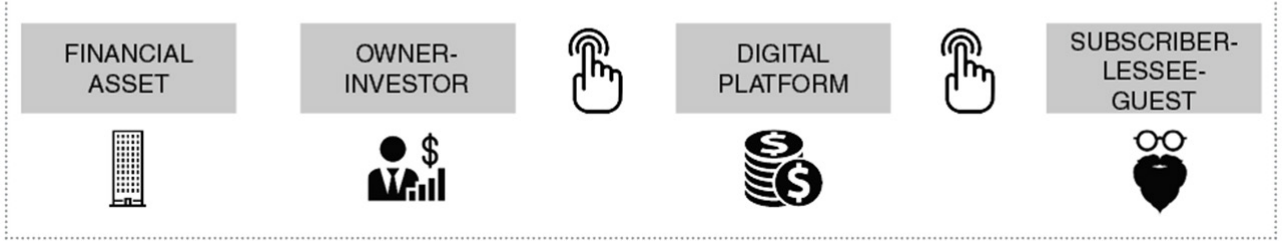

Digital-financialized relationship.

Source: authors (2021). 
to reinvest capital in real estate, especially in the post-2008 context. During this period, the transformation of housing into a global asset intensified. Although we advanced the understanding of new models and strategies to commercialize living services across Brazil, this phenomenon still demands continued studies, especially at the level of each specific city. Nevertheless, it is already possible to identify negative impacts on fair access to housing. The search for double profitability of the built space, in construction and occupation, recreates social and spatial inequality patterns. Additionally, it seems to prevent urban management from building a city focused on meeting local culturally shaped needs in the face of externally imposed market utilitarianism.

Our analysis advances the understanding of new strategies undertaken by the real estatefinancial complex to extract more income from neighborhoods well-served by infrastructure systems, especially in metropolises. Besides that, we also deepened the understanding of how these strategies may push the housing deficit by making these central neighborhoods more profitable when new technologies operate uncomplicated, flexible, and shortterm rentals. These business models indicate a barrier in the access of the working-class to housing in central areas due to the prices charged. It may reproduce the chronic logic of peripheral housing and the need to commute daily to central jobs.
There seems to be some innovation component behind all examples of strategies, companies, and enterprises discussed in this article. These components range from nonbureaucratic contracts to fully digital ones and the possibility of on-demand additional services. Multiple facilities approximate the commercialization of housing to a service for the tenant-lessee and investment to the landlord-lessor. Innovations allow for a surplus achievement in these businesses because new models make viable, besides profits from the urban land the architectonic artifact, profits from the innovation itself, which differs from the traditional market by offering novel services and facilities that recreate digital creative capitalism.

To what extent, however, the innovation surplus opposes the social function of property is an open question. We may hypothesize that those new living models of real estate produced as investment difficult for the possibilities of affordable housing for lowerincome families in good neighborhoods. Our discussion leaves another open question to future investigation: is it even possible to imagine a scenario in which housing is an investment and, at the same time, a right to the city? As of now, our analyses denote that new forms of exploring urban space by the real estate-financial complex recreate challenges of the right to the city to the extent that innovation increases housing costs. 


\section{[I] https://orcid.org/0000-0001-7615-0273}

Pontifícia Universidade Católica do Paraná, Escola de Belas Artes, Programa de Pós-Graduação em Gestão Urbana. Curitiba, PR/Brasil.

rafael@kalinoski.rocks

\section{[II] https://orcid.org/0000-0002-7346-1938}

Pontifícia Universidade Católica do Paraná, Escola de Belas Artes, Programa de Pós-Graduação em Gestão Urbana. Curitiba, PR/Brasil.

mario.p@pucpr.br

Translation: this article was translated from Portuguese to English by Rafael Kalinoski.

\section{Notes}

(1) According to the document Mapas das Construtechs e Proptechs, published by Terracotta Ventures in the first half of 2021, there are 839 active startups acting throughout the entire cycle of projects: construction, sales, and rentals. The document is available at: https://www. terracotta.ventures/mapa-de-startups-2021.

(2) According to B3, sponsored Brazilian Depositary Receipts (BDRs) are mobiliary values issued in Brazil that are backed in assets, typically stock shares, issued in other countries. Available at: http://www.b3.com.br/pt_br/produtos-e-servicos/negociacao/renda-variavel/braziliandepositary-receipts-bdrs-patrocinados-niveis-i-ii-e-iii.htm.

(3) Available at: https://open.spotify.com/episode/5XsOU7g6pQSatOdWIObGiq?si=hnIHfYDHRwCJjP $8 \mathrm{~S} 1 \mathrm{yf} 7 \mathrm{xQ}$.

(4) All public information about the REIT can be found at https://fii.housi.com.br/.

(5) In trading, to value stocks and REIT quotas, the P/EV indicator below 1 suggests the share is cheaper than what it is Worth, whole the P/EV above 1 indicated it could be more expensive than what it is worth because it is negotiated a price above the enterprise value of that share/ quota. How-ever, this is only one of many indicators considered by investors. 
(6) This financial market indicator expresses the relationship between distributed dividends and the price of shares/quotas. The higher the DY, the more attractive the share/quota is for investors looking for income, which is paid monthly in REITs. The difference here is that, instead of buying an entire property (tangible real estate investment) and managing its rent, the investor can make smaller in-vestments through quotas (intangible investment). Mieli's (2008) work clarifies how REITs work in Brazil and how they emerged in the local market as a partial replacement for tangible real estate invest-ment.

(7) Market jargon referring to companies valued at one billion USD before going public. Brazilian startups Loggi, 99, iFood, Movile, Nubank, Gympass, and Quinto Andar fall into this criterion.

\section{Referências}

AALBERS, M. B.; HAILA, A. (2018). A conversation about land rent, financialization and housing. Urban Studies, v. 55, n. 8, pp. 1821-1835. DOI: 10.1177/0042098018759251.

ABRAMO, P. (1995). A regulação urbana e o regime urbano: a estrutura urbana, sua reprodutibilidade e o capital. Ensaios FEE, v. 16, n. 2, pp. 510-555.

ARANTES, O.; VAINER, C.; MARICATO, E. (2002). A cidade do pensamento único: desmanchando consensos. Petrópolis, Vozes.

ARBEX, P.; SAMOR, G. (2020). Morar nas megalópoles virou um inferno. A Yuca diz ter a solução. Brazil Journal, 29 jan. Disponível em: https://braziljournal.com/morar-nas-megalopoles-virouum-inferno-a-yuca-diz-ter-a-solucao. Acesso em: 3 jul 2021.

AUGUST, M. (2020). The financialization of Canadian multi-family rental housing: From trail-er to tower. Journal of Urban Affairs, v. 42, n. 7, pp. 975-977. DOI: 10.1080/07352166.2019.1705846.

CAPELAS, B. (2020). Startup de aluguel de casa compartilhada, Yuca lança fundo imobiliário de $\mathrm{R} \$$ 40 mi. Terra, 26 nov. Disponível em: https://www.terra.com.br/noticias/tecnologia/inovacao/ startup-de-aluguel-de-casa-compartilhada-yuca-lanca-fundo-imobiliario-de-r-40-mi,bd9275013 35bdc596e338343c265e660h1glptsa.html. Acesso em: 11 mar 2021.

CAVALCANTE, A. et al. (2018). Financialization and Space: Theoretical and empirical contributions. Revista Brasileira de Estudos Urbanos e Regionais, v. 20, n. 2, pp. 193-220. DOI: 10.22296/2317-1529.2018v2 On2p193.

CHARLES, S. L. (2020). The financialization of single-family rental housing: An examination of real estate investment trusts' ownership of single family houses in the Atlanta metropolitan area. Journal of Urban Affairs, v. 43, n. 8, pp. 1321-1341. DOI: 10.1080/07352166.2019.1662728

D'ÁVILA, M. Z. (2020). Fundos imobiliários residenciais ganham espaço na Bolsa, com foco em aluguéis, incorporação e compra e venda. InfoMoney, 30 jul. Disponível em: https://www.infomoney. com.br/onde-investir/fundos-imobiliarios-residenciais-ganham-espaco-na-bolsa-com-foco-emalugueis-incorporacao-e-compra-e-venda/. Acesso em: 11 mar 2020. 
DIAS, M. C. (2021). Startup que quer mudar a moradia urbana, Yuca capta R\$ 56 milhões. Exame, 22 jun. Disponível em: https://exame.com/pme/startup-yuca-capta-56-milhoes/. Acesso em: 22 jun 2021.

EPSTEIN, G. A. (2005). Financialization and the world economy. Cheltenham e Northampton, Edward Elgar Publisher.

FERNANDEZ, R.; AALBERS, M. B. (2016). Financialization and housing: between globalization and varieties of capitalism. Competition and Change, v. 20, n. 2, pp. 71-88. DOI: 10.1177/1024529415623916.

FIX, M. (2009). Uma ponte para a especulação - ou a arte da renda na montagem de uma "cidade global". Caderno CRH, v. 22, n. 55, pp. 41-64.

(2011). Financeirização e transformações recentes no circuito imobiliário no Brasil. Tese de doutorado. Campinas, Universidade Estadual de Campinas.

FIX, M.; PAULANI, L. M. (2019). Considerações teóricas sobre a terra como puro ativo financeiro e o processo de financeirização. Brazilian Journal of Political Economy, v. 39, n. 4, pp. 638-657. DOI: 10.1590/0101-31572019-2954.

GRIFFITH, E. (2020). Airbnb prices I.P.O. at $\$ 68$ a share, for a $\$ 47$ billion valuation. The New York Times, 9 dez. Disponível em: https://www.nytimes.com/2020/12/09/business/airbnb-ipo-price.html. Acesso em: 11 mar 2021.

GUIRONNET, A.; ATTUYER, K.; HALBERT, L. (2015). Building cities on financial assets: the financialisation of property markets and its implications for city governments in the Paris city-region. Urban Studies, v. 53, n. 7, pp. 1142-1464. DOI: 10.1177/0042098015576474.

HALBERT, L.; ATTUYER, K. (2016). Introduction: The financialisation of urban production: Conditions, mediations and transformations. Urban Studies, v. 53, n. 7, pp. 1347-1361. DOI: 10.1177/0042098016635420.

HARVEY, D. (2005). A produção capitalista do espaço. São Paulo, Annablume.

(2008). O neoliberalismo: história e implicações. São Paulo, Loyola.

(2012). O Direito à cidade. Lutas Sociais, v. 29, pp. 73-89.

IBGE - Instituto Brasileiro de Geografia e Estatística (2020). Regiões de influência das cidades 2018. Rio de Janeiro, IBGE.

IOANNOU, S.; WÓJCIK, D. (2021). Finance and growth nexus: an international analysis across cities. Urban Studies, v. 58, n. 1, pp. 223-242. DOI: 10.1177/0042098019889244.

KLINK, J.; SOUZA, M. B. de (2017). Financeirização: conceitos, experiências e a relevância para o campo do planejamento urbano brasileiro. Cadernos Metrópole, v. 19, n. 39, pp. 379-406. DOI: 10.1590/2236-9996.2017-3902.

KRIPPNER, G. R. (2005). The financialization of the American economy. Socio-Economic Review, v. 3, pp. 173-208. DOI: 10.1093/SER/mwi008.

LACERDA, N.; BERNARDINO, I. L. (2020). Ressemantização das áreas centrais das cidades brasileiras e mercado imobiliário habitacional: o caso recifense (Brasil). Cadernos Metrópole. São Paulo, v. 22, n. 49, pp. 913-934. DOI: 10.1590/2236-9996.2020-4911. 
LÓPEZ, L. M. (2020). El capital inmobiliário-financeiro y la producción de la ciudad latinoa-mericana hoy. Cadernos Metrópole. São Paulo, v. 22, n. 49, pp. 665-682. DOI: 10.1590/2236-9996.20204901.

MARTINS, F. M. (2020). Agentes, produtos e implicações da produção imobiliária de habitação multifamiliar em Curitiba, 2010-2018. Dissertação de mestrado. Curitiba, Universidade Federal do Paraná.

MATTOS, C. (2007). Globalizacion, negocios inmobiliarios y transformación urbana. Nueva Sociedad, n. 212, pp. 82-96.

MELO, E. O. de. (2021). Financeirização, governança urbana e poder empresarial nas cidades brasileiras. Cadernos Metrópole. São Paulo, v. 23, n. 50, pp. 41-66. DOI: 10.1590/2236-9996.2021-5002.

MIELE, S. A. de F. (2008). O movimento da economia financeira: a dinâmica imobiliária de São Paulo. Dissertação de mestrado. São Paulo, Universidade de São Paulo.

PANIZZI, W. (2020). Rent-seeking urbano, planejamento urbano e valor imobiliário: quem manda e desmanda na cidade ? e-metropolis, ano 11, n. 40, pp. 18-24.

PROPERTY NOTIFY (2020). SpareRoom Acquires Rival Roomgo - Creating World's Largest Roomate Finding Service. Property Notify, 7 set. Disponível em: https://www.propertynotify.co.uk/news/ press-releases/spareroom-acquires-rival-roomgo-creating-worlds-largest-roommate-findingservice/. Acesso em: 13 mar 2021.

RUFINO, M. B. C. (2012). Incorporação da metrópole: centralização do capital no imobiliário e nova produção de espaço em Fortaleza. Tese de doutorado. São Paulo, Universidade de São Paulo.

SAMBRANA, C. (2021). A virada de chave da Housi agora passa pelas "franquias". Neofeed, 4 jan. Disponível em: https://neofeed.com.br/blog/home/a-virada-de-chave-da-housi-agora-passapelas-franquias/. Acesso em: 11 mar 2020.

SANFELICI, D. (2013). Financeirização e a produção do espaço urbano no Brasil: uma contribuição ao debate. Eure, v. 39, n. 118, pp. 27-46.

SANFELICI, D.; HALBERT, L. (2016). Financial markets, developers and the geographies of housing in Brazil: A supply-side account. Urban Studies, v. 53, n. 7, pp. 1465-1485. DOI: 10.1177/0042098015590981.

(2019). Financial market actors as urban policy-makers: the case of real estate investment trusts in Brazil. Urban Geography, v. 40, n. 1, pp. 83-103. DOI: 10.1080/02723638.2018.1500246.

SANTORO, P. F.; ROLNIK, R. (2017). Novas frentes de expansão do complexo imobiliário-financeiro em São Paulo. Cadernos Metrópole. São Paulo, v. 19, n. 39, pp. 407-431. DOI: 10.1590/22369996.2017-3903.

SILVA, M-V.G.; PROCOPIUCK, M. (2019). A produção científica sobre gestão urbana: análise bibliométrica de 2010 a 2017. Eure, v. 45, n. 136, pp. 281-95.

SOARES, P. R. R. (2020). Metrópoles e cidades na atualidade. e-metropolis, ano 11, n. 40, pp. $34-42$.

SORKIN, A. R. et al. (2020). Airbnb's Stunning I.P.O. The New York Times, 11 dez. Disponível em: https:// www.nytimes.com/2020/12/11/business/dealbook/airbnb-ipo-chesky.html. Acesso em: 11 mar 2021. 
THEODORE, N.; PECK, J.; BRENNER, N. (2009). Urbanismo neoliberal: la ciudad y el imperio de los mercados. Temas Sociales, n. 66, pp. 1-11.

VALFRÉ, L. G.; RIBEIRO, M. G. (2020). Um jeito de morar ou de investir ? e-metropolis, ano 11, n. 42, pp. 31-40.

VEJA (2019). Startup de aluguel de imóveis Quinto Andar é o nono unicórnio brasileiro. VEJA, 10 set. Disponível em: https://veja.abril.com.br/economia/startup-de-aluguel-de-imoveis-quintoandar-e-o-nono-unicornio-brasileiro/. Acesso em: 11 mar 2021.

WEIGERT, I. (2020). Entre a preservação e o desenvolvimento: a rua Riachuelo na área central de Curitiba. Dissertação de mestrado. Curitiba, Universidade Federal do Paraná.

Received: March 31, 2021

Approved: June 18, 2021 